\title{
RÁBA ÉS SEBES-KÖRÖS MENTI BELVÍZJÁRTA TERÜLETEK SZEREPE A VÉDETT TERÜLETEK RENDSZEREÉBEN
}

THE ROLE OF AREAS EXPOSED TO

EXCESS WATER NEAR RÁBA

AND SEBES-KÖRÖS RIVERS IN THE

PROTECTED AREAS' SYSTEM

$\begin{array}{ll}\text { SZERZŐ/BY: VARGA DALMA, HUBAYNÉ } & \text { HTIPS://DOI.ORG/ } \\ \text { HORVÁTH NÓRA, MÓDOSNÉ BUGYI ILDIKÓ } & 10.36249 / 57.5\end{array}$

BEVEZETÉS

A belvízi elöntés Magyarország síkvidék területeinek jelentős hányadát, min egy 73,52\%-át érinti valamilyen mértékben. A 2015-ben elkészült komplex belvíz-veszélyeztetettségi térképezés eredményeként megállapitható, hoogy a fenti adat az $1 \%$-nál nagyobb valószínűséggel történő elöntést mutatja. A gyakrabban visszatérő belvízi elöntések aránya (jelen esetben 10\%-nál nagyobb valószínüséggel bekövetkezó elöntési valószínűség) az alföldi terileteken mintegy 24,42\% (OVF adatszolgáltatás 2020). A belvíz ${ }^{2}$ kialakulásához a folyószabályozásokon kívül számos tényező járult hozzá - különösen az antrozogén beavatkozások, mi például a beépitések, burkolt felületek arányának növekedése, az intenzív gyüzemi mezőgazdálkodási tevékenység -, de a természeti adottságoknak van szerepük benne. Számos kutatás készül(t) a belvízi elöntés gazdasági szempontú következményeinek feltáráára, az ökológiai potenciáljával ezzel szemben viszonylag kevés kutatás fo Jakozik, pedigen idószakosatán ito verzitás növeléś́hez a vát tozatossabb

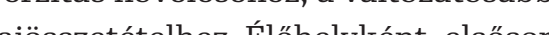
on időz b́ln as a táplákozohelykent szoltok (pl. mazenos helyeket kedveló allaA beluzo szakotok számára. vizes gyepezo csatornakban, a bel cuvernzzen belvzes szántokon számos for ês vest novenyfaj elóordulását igazolták kutatások (Molnár
INTRODUCTION

Excess water inundation endangers a ands. As a result of the complex excess water risk mapping 1 completed in 201 this statement shows the extent of flooding occurs with a probability of more than $1 \%$. The proportion of more frequent excess water inundation (in th particular case the chance of flooding occurs with a probability of more than $10 \%$ in the Great Plain is about $24.42 \%$ (General Directorate of Water Management - data supplying, 2020). Besides river regulations, numerous factors have contributed to the formation of excess water, ${ }^{2}$ especially anthropogenic interventions, such as the increasing intertion of constructions, paved areas, the intensive agricultural activity, the inural conditions tant role. Several studies havimp made and are in progress to revel the while its ecological potential is relatively slightly explored, ath ugh these periodically flooded areas contribute to biodiversity increasing and to create a diversification among species. These areas function as habitats primarily as feeding grounds for animals (for exanple bids, dragonles, which prefer wetlands. Research works have confirmed the presence of numerous rare and endangered plant species in drainage canals, on grasslands expose to excess water and on special agricultural fields with mud vegetation (Moln - Lukács 2014). Nowadays, in order to mitigate the effects of climate change, the role of wetlands and water retention become appreciated, more and $\mathrm{m}$ international and national strategies and programs give priority to the role of pean Green Deal 2019). Therefore, areas exposed to excess water are ecologically uable than areas with similar water. These areas create a specific coherent, periodic network of blue an green infrastructure. The quantified ind cators of their natural and landscape values besides the presence of protected species and the naturalness of habitats, the various nature protections the aim of our article is to reveal this.

METHODS designations in the sample areas order to reveal the correlations between areas exposed to excess water ${ }^{3}$ and . nalyzed among natural areas protected by special legislation the existence f national park (NP), protected landcape area (PLA), nature conservation area (NCA), in the case of European (he presence of Natura 2000 Special Protecion Area (Natura 2000 SPA), Natura oo Special Areas of Conservation (Natura $2000 \mathrm{SAC}$ ). In addition to the mentioned types, National Ecological Network (NEN) and its three parts: core zone, buffer zone and ecological corrido were also taken into account. During the research, we analyzed the correlations by comparing the characterisics and protections of two drainage districts ${ }^{4}$ (01.08. drainage district near Rába river with an area around 13.370 hectare and 12.04 drainage district nea Sebes-Körös river with an area around
1 Complex excess water risk map: Wit hin Project 'Flood risk mapping and B/og-12-2013-0001) the excess water rist mapping activity has been implemented management planning (httpr) 2 Excess water: "the getting of a land under water (water from groundwater is translation (178/2010. (V. 13.) Government decree. 1.\& (2,c)). "a phenomenon, a spectlc water-type of flattands that nently and relatively on large areas" own translation (Pálfai 2004) 3 Area exposed to excess water: Area the appearance of excess water can be expected generally even in the case of (Szlávik to excess water: it is also defined in the National Spatial Planning of Hungary include the deeper parts of lowlensts wat moderately sloping areas, where some of the local precipitation accumulates in theater quantities and moref water in own translation) (Act CXXXIX of 2018.) 4 Drainage district: A well-defined part of drainage system that is suitable for the of protection. Its area, boundaries are defined by law. (Szlavik 2013) (10/1997 (VIII.7.) KHVM rend.) 
- Lukács 2014). Napjainkban a klímavaltozás hatásainak enyhitése érdekében a vizes élőhelyek és a vízvisszatartás szerepe felértékelődik, egyre több nemzetközi és hazai stratégia, program kezeli kiemelten a víz szerepét (pl. az ún. Európai Zöld Megállapodás 2019). A belvízjárta területek mindeze miatt ökológiai szempontból értékesebbek, mint a hasonló adottságú, nem belvizes területek. Ezek a területek sajátos, összefüggő, időszakos kékés zöldinfrastruktúra hálózatot képeznek, melyek természeti, táji értékein számszenúsíthetó mutatói a védett fajok lőfordulása és az élöhelyek termé szetessége mellett a különfóle tészetvédelmi oltalmán, védettśg künk ennek feltárását tüzi ki célul.

\section{MÓDSZER}

A belvízjárta ${ }^{3}$ és a természetvédelmi oltalom alatt álló területek közötti összefüggések vizsgálatához a következô teruleti kjeloleseket elemeztuk a míntar ballyal vedett tenószeti toruletek koz nenzeti park, tájvédelmi korzet, termé szetvédelmi tarllet megletét, az európai Natura 2000 különleges madárvédelmi Natura 2000 különleges madárvéde területek (Natura 2000 SPA), Natura 2000 kulonleges természetmegőrzési területek (Natura $2000 \mathrm{SAC}$ ) jelenléte vizsgáltuk. A felsoroltakon kívül az Országos Ökológiai Hálózatot (OÖH) és ennek három részelemét (magterület, pufferterulet és okologiai folyosó) is számításba vettük. A kutatás során az összefüggéseket két belvízvédelm (a 13370 hektár kiterjedésű Rába menti 01.08-as és a 34 0oo hektáros Sebes-Körös menti 12.04-es) szakasz jellemzőinek, védettségeinek összevetésével, térinformatikai eszközök alkalmazásával elemeztük: valamint az eredményeket összehasonlitottuk az országos adatokkal is. Síkvidéki. területként a hazai nagytájak közül Kisalföldet és az Alföldet vettük szám tásba. A kutatásban az Országos Vízügyi Főigazgatóság, az Észak-dunántúli Vízügyi Igazgatóság és a Körös-vidéki Vízügyi Igazgatóság belvízjárta területekre, illetve a vizsgált belvízvédelm szakaszokra rendelkezésre bocsátott adatait, a természetvédelmi nformácí́s rendser (httpa), vahom vizizigy a a (́rkép készíse során (3. és 5 ábra)

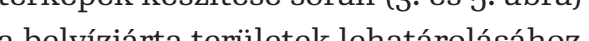
a belvízelöntési gyakoriság térkép 1. colve

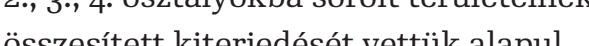
Ebsta Ebben a cikkben nem térunk ki az orszagos vedettség alatt álo, torvény erejénel fogva vegett (ex lege) lápokra es szikes tavakra, a Ramsari területekre bioszféra rezervátumokra, érzékeny ter mészeti teruletekre, valamint a mintaterületeken jelenlévő vízhez kötődó egyed tájértékek szerepére sem, ezek feldolgozása későbbi kutatásaink tárgya lesz.
3 Belvizjárta terület: "a belvizzel gyakran és talajadortat, amelynek domborzati nésére általóban més viszonylag kisecsapadék esetén is számitani lehet." (Szlavik 2013) Rendszeresen belvizjarta

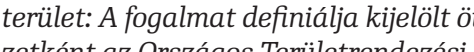
Terv is ssikvidéki vagy enyhe lejtésviszonyokkal rendelkezó területek azon mellyi csapadék ésy része átmenenti ahol a lesleg formíjiban nagyobb mennuise ben és gyakorisággal összegyúliki) (2018. Evi CXXXIX. TV.)

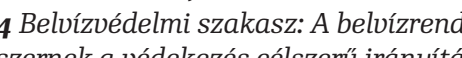
sához és végrehajtásához alkalmasan meghatarozott resze. Teruletet, határat

jogszabály állapitja meg. (Szlávik 2013)
(11/1997. (VIII17) KHVM rend)
1. Táblázat/

Table a: Védett és Comparison of

álló belviziárta

megoszalánanak
összevetése az

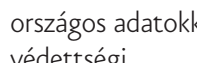

kategóriánként

\begin{tabular}{|c|c|c|c|c|c|c|c|c|}
\hline 1 & 2 & 3 & 4 & & 5 & 6 & 7 & 8 \\
\hline & $\begin{array}{l}\text { Védett területek } \\
\text { országos területti } \\
\text { megoszlása (\%) / } \\
\text { Distribution of } \\
\text { protected areas in } \\
\text { national scale (\%) }\end{array}$ & $\begin{array}{l}\text { Védett területek } \\
\text { sikvidéki területe } \\
\text { Distribution of prote } \\
\text { flatlands }(\%)\end{array}$ & 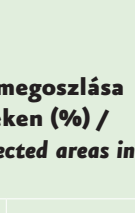 & & 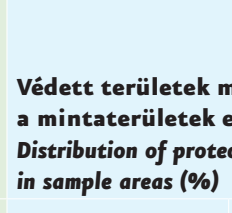 & 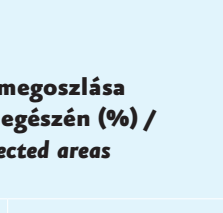 & 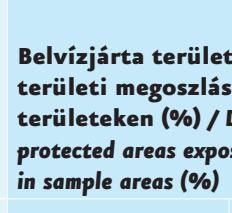 & $\begin{array}{l}\text { tek védettségének } \\
\text { sa a minta- } \\
\text { Distribution of } \\
\text { sed to excess water }\end{array}$ \\
\hline 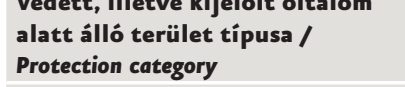 & $\begin{array}{l}\text { Országos / } \\
\text { National scale }\end{array}$ & Kisalföld & Affoldd & & $\begin{array}{l}\text { I. mintaterület / } \\
\text { I. sample area }\end{array}$ & $\begin{array}{l}\text { III. mintaterület / } \\
\text { II. sample area }\end{array}$ & $\begin{array}{l}\text { I. mintaterület / } \\
\text { I. sample area }\end{array}$ & $\begin{array}{l}\text { II. mintaterület / } \\
\text { II. sample area }\end{array}$ \\
\hline Nemzeti Park / National park & 5,26 & 4,00 & & 4,27 & 0,00 & 15,88 & 0,00 & 9,48 \\
\hline 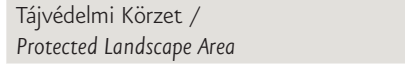 & 3,41 & 2,38 & & 2,78 & 0,00 & 0,00 & 0,00 & 0,00 \\
\hline 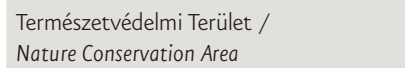 & 0,33 & 0,08 & & 0,37 & 0,00 & 0,00 & 0,00 & 0,00 \\
\hline Natura 2000 SPA & 14,77 & 10,30 & & 13,99 & 1,64 & 14,53 & 2,51 & 6,75 \\
\hline Natura 2000 SAC & 13,89 & 6,09 & & 12,89 & 10,80 & 12,77 & 11,00 & 11,66 \\
\hline OÖH - magterület / NEN - core zone & 19,49 & 12,61 & & 14,13 & 2,56 & 15,76 & 4,08 & 9,25 \\
\hline OÖH - pufferterület / NEN - buffer zone & 7,77 & 7,95 & & 9,43 & 3,01 & 8,90 & 3,17 & 9,45 \\
\hline 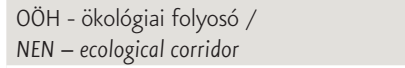 & 9,18 & 7,31 & & 8,55 & 15,72 & 12,61 & 17,40 & 13,24 \\
\hline $\begin{array}{l}\text { Egyes védettségegk \%-os arínyainak } \\
\text { osszege / Total distribution } \\
\text { of forcecter ores }\end{array}$ & 74,10 & 50,72 & & 66,41 & 33.73 & 80,45 & 38,16 & 59.83 \\
\hline 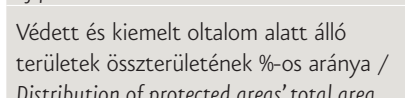 & 4477 & 30.5 & & 4071 & 2273 & 43,36 & 1826 & 2231 \\
\hline
\end{tabular}

34.00o hectare) using GIS methods; the results were also compared with national data. As flatlands, the Little Plain and the Great Plain, delimitated as the major Hugatan londscape catesories, were taken into account In this research we used the data provided by the General Directorate of Wate Management, North-Transdanubian Water Directorate, Körös Valley District Water Directorate for the areas expose to excess water and drainage districts, the nature conservation system (httpa) and the online database of water atlases (http3). During the mapping of sample areas (Figure 3, Figure 5.) we took as a basis the total extent of excess water inundation frequency map's classes 1., 2., 3., 4. to delimit the areas exposed to excess water.
In this article, we don't analyze ex lege (protected due to one single aw) bogs and salt-marshes, Ramsar sites, biosphere reserves, vulnerable atural areas or the role of the so-called nique landscape features, which elate to waters on the sample areas hubject of

RESULTS

The results of the analysis are summarized in Table 1 by protection categories in terms of percental proportion calculated on the basis of the areas' extent. We compared the protected areas' extent to the country's area in the second column to the Little Plain in the third column, 

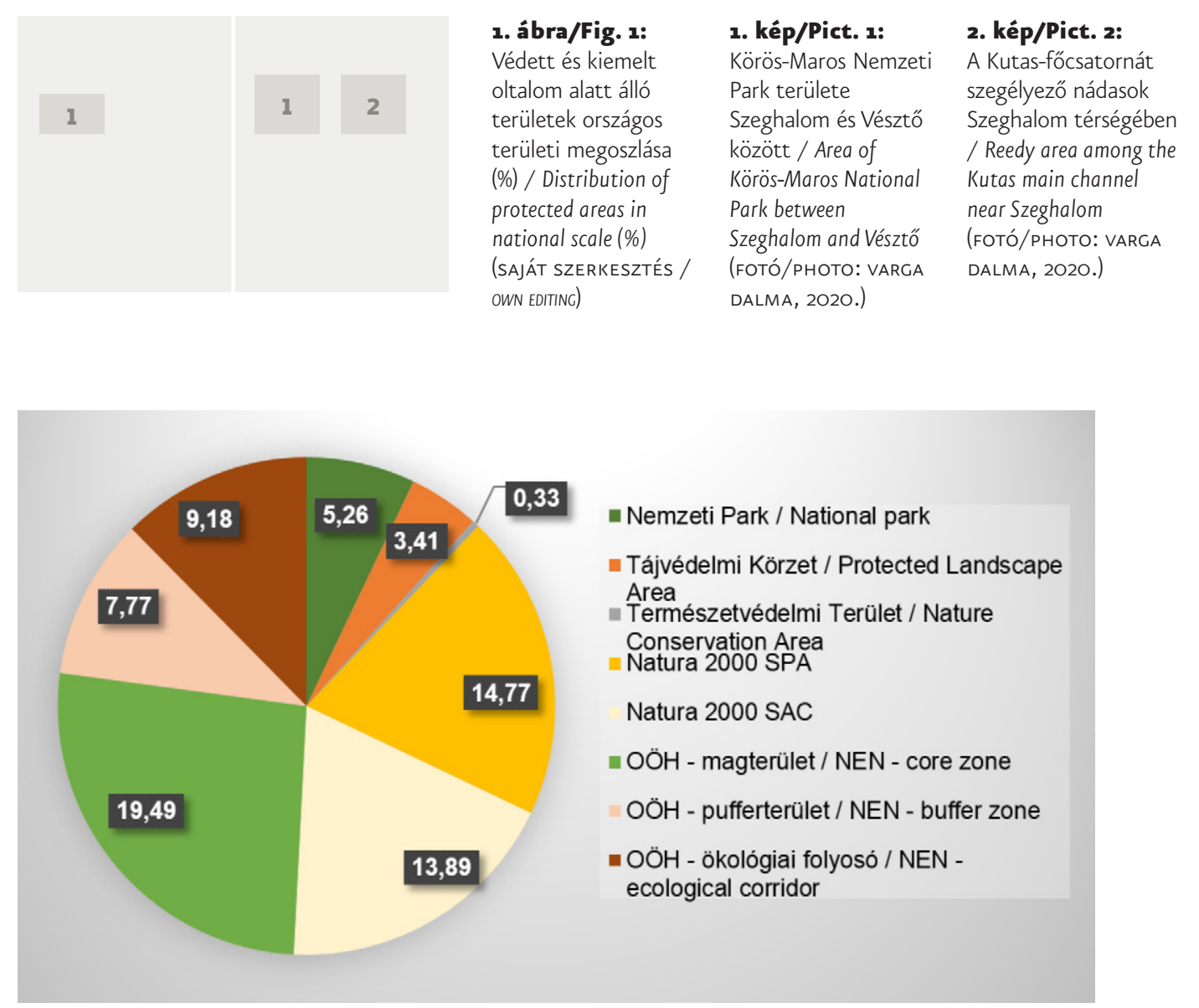

EREDMÉNYEK

Az elemzés adatait az 1. táblázatban védettségi kategóriánként foglaltuk össze a területi kiterjedés alapján számított százalékos arányban megadva. A 2. oszlopnál az ország, a 3. oszlopnál a Kisalföld, a 4. oszlopnál az Alföld, az 5-6. oszlopoknál a mintaterületek összterületé hez, a 7-8. oszlopoknál a mintaterületer belvíziérta területéhez $(100 \%)$ viszonytottuk a védelem alatt áló terïletrésze tottukrését Az orsź́

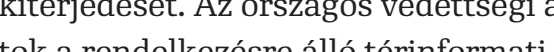
tai adatbázisokból sź méńs lolóllított összesito adat táblázal untón tük a védett ́́s a kie tló terülek terileti százalón alló terún sora az összes elemzett védettosi sóriáb tartozó terïl ve (NP, TK, TVI, górába tartozóötuletek (NR, IK, IVI, Naturazooo, OÖH) összemásolását, egyösszerületének \%-os arányát mutatja.

Védettségek országos, alföld és kisalföldi referenciaértékeinek elemzése (táblázat 2-4. oszlopai) A táblázatban a védettségeket országo területi megoszlásban, illetve a síkvidé területek (Kisalföld, Alföld) tekintetében

is elemeztük. A különböző védettségek országos megoszlását az 1. ábra mutatja be. A két tájegység összevetéséből kirajzolódik, hogy az egyes védettségek területi részaránya hasonló, viszont a Natura 2000 különleges természetmegốrzési erïletek és a természetvédelmi terïetek aránya a Kisalföldön jóval terunyabb. A védett területek összterületének aránya alapján a Kisalföld 30.5\%-a míg az Alföld 40,71\%-a áll oltalom alatt az elemzett kategórí́k alapjén. A külänbś́g oka vélhetóen a jelenlegi tájhónlatokban és a tájváltozési tendencíábro kno

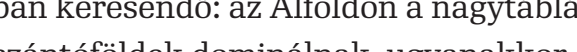
viszonylag kis az összeügonakn

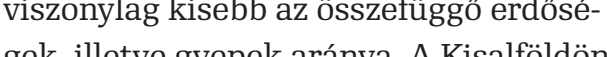

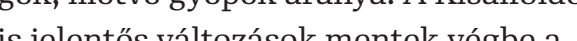
tájban az évsź́zadok són, de oubb fotba mezer tálásra keriltek ol van teriletek ( éáásra kerultek olyan teruletek (gyepek, erdód), amelyek magasabb termeszet-

\section{Védettségek megoszlásának}

elemzése a mintaterületek

eljes területe tekintetébe

(táblázat 5-6. oszlopai)

Az I. mintaterulet (Rába menti 01.08. bel-

vizvédelmi szakasz) 22,73\%-a érintett az

elemzett kategóriák valamelyikével, így
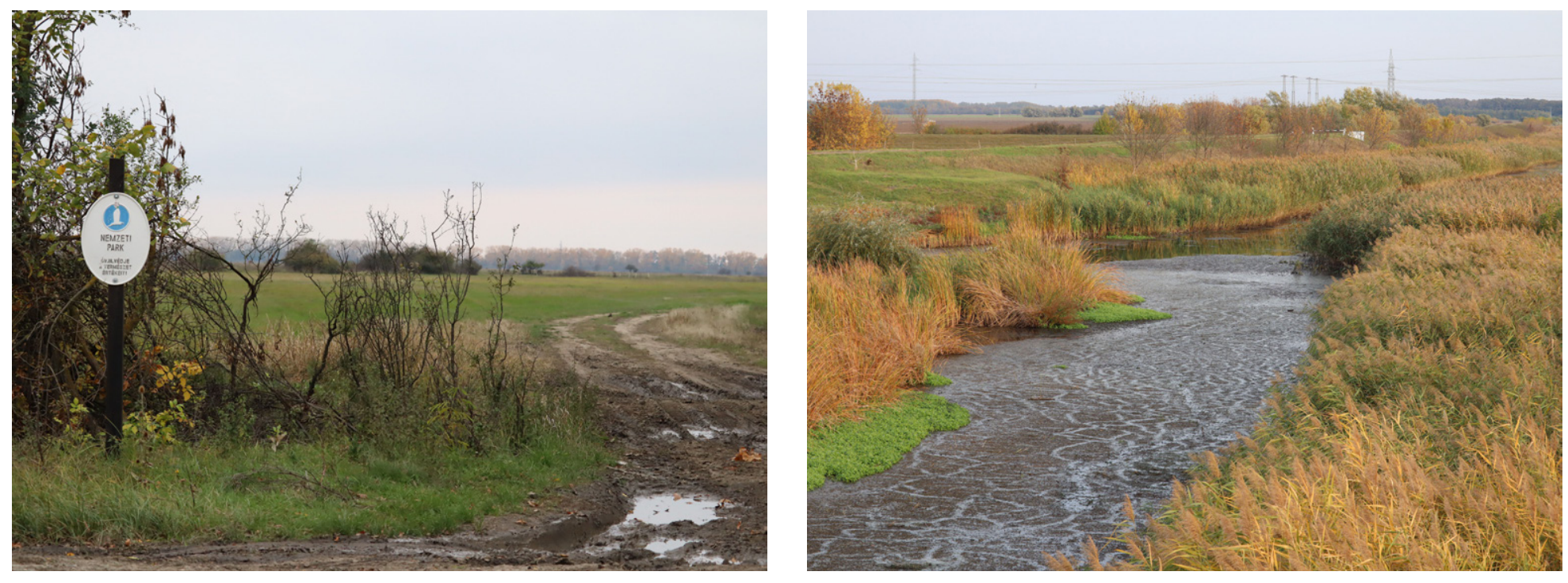

to the Great Plain in the fourth column to the total extent of sample areas in the fifth, sixth columns and to the exposed to excess water of sample areas in the seventh, eighth column The national data are calculated on the basis of the available GIS databases calculated by area measurement. In the penultimate row of the table, we sumn rized the values of the protected areas' areal percental proportion. The last row of the proportion of the protected areas' total extent calculated by layering all analyzed protection categories (NP, PLA, NCA, Natura 2000 areas, NEN areas).

Analysis of reference values of protection areas in national scale and on the Little Plain and Great Plain (columns 2-4 of the table) In the table, we analyzed the distribution of protected areas in national scale and in the flatlands (Little Plain, Great Plain). Figure 1 shows the national dis bution of different protection categories. The comparison of these landscape areas shows that the proportion of protected areas is similar, but the ratio of Natura 2000 SAC and nature conse vation areas is much lower in the Little Plain. Based on the proportion of the total area of protected areas, $30.5 \%$ of the Little Plain and $40.71 \%$ of the Great Plain are protected by the analyzed categories. The difference's reason can be presumably found in the current landuses and landscape changing trends: the Great Plain is dom nated by large coherent agricultural lands, at the same time the proportion of contiguous forests and grasslands is relatively smaller. In the Little Plain, significant changes also have proceeded in the landscape during centuries, however areas (grasslands, forests), that have higher nature conservation value, have been preserved in several patches or have been rehabilitated.

Analysis of distribution of protected reas in sample areas' total extent (columns $5-6$ of the table)

$2.73 \%$ of the I. sample area (01.08. drainage district near Rába river) is covered by any of the analyzed categories, so totally 3038.42 hectare is protected. The total distribution of protected areas is $33.73 \%$. There is not any national parks, protected landscape areas, nature conservation areas in forests along Rába and Rábca rivers and the streams are parts of Natura this sample site, but most of the gallery 

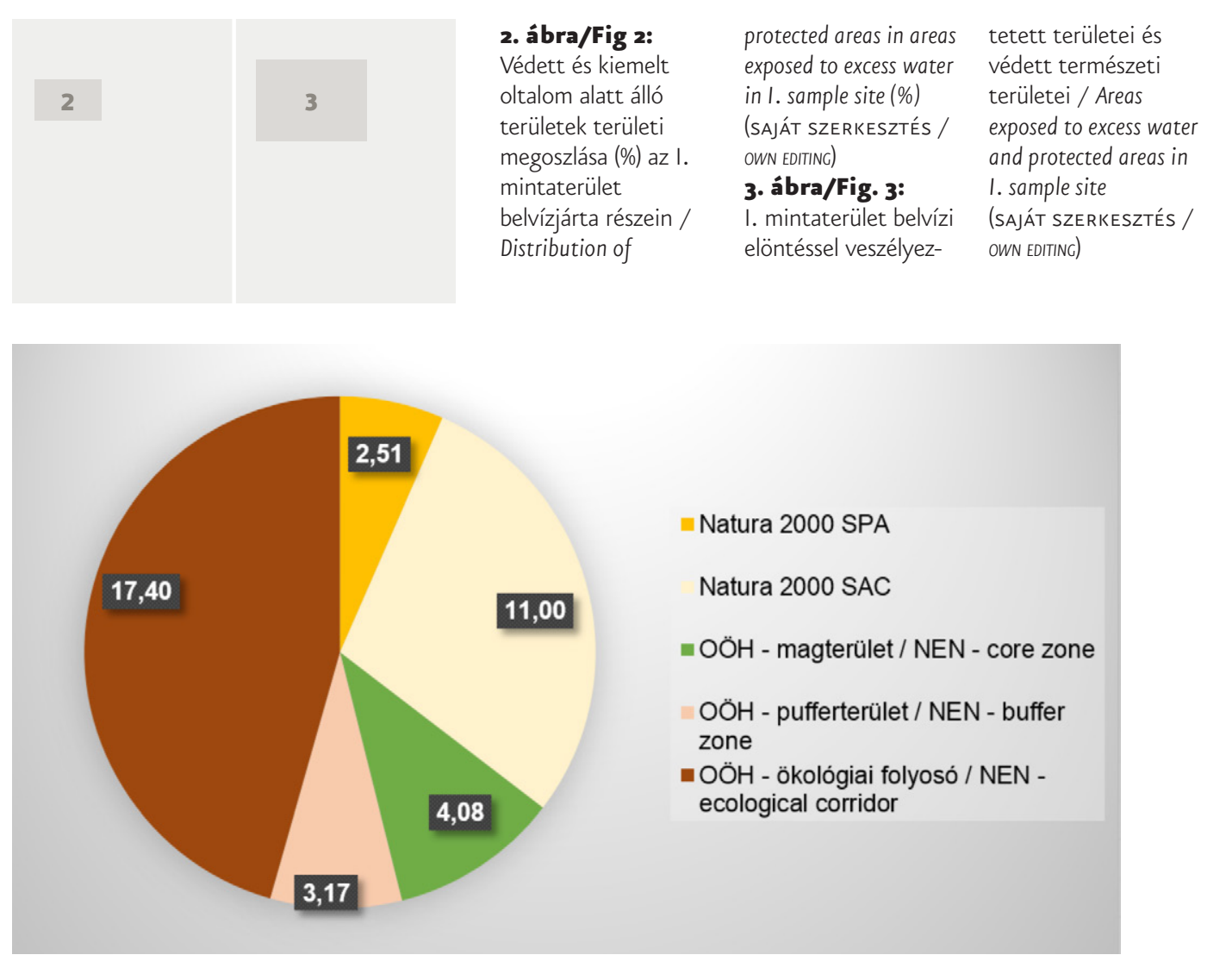

összesen 3038,42 ha védett. A védettség alatt álló területek területi arányainak összegzett értéke $33.73 \%$. Nemzeti park, tájvédelmi körzet és természetvê delmi terület nem található itt, viszon Natura 2000 terület, illetve az Országos Ökológiai Hálózat része a kis págos Okolagint a Rába és Rábca patahúzódó galériaerdók zömo Különleges természetmego ges terso (Hába) kijelölt a mintat Hio (1) azaz 1443,92 ha, az okologiai foly

\section{A II mintoterïlet (Sebes Körös ment}

A I. miztátétlet (Sebes-Koros ment 12.04. belve lyikével, íg összes Nagyon magas, 80,45\%-os a védettséNagy gek tertlet ar nyan melyno oka az hogy sok helyentobbere Aedettség is érintigyanazt a teruletrést. A védett teruletek kozal ki kell eme a Koros-Maros Nenzeti Parkot, amely foltban a területet - köztük például Szegfoltban a teruletet - koztuk peldául Sze halom és Vésztó környékét (1. fotó). Tásvédelmi körzet es természetvédelmi terület nem található a vizsgált belvízvédelmi szakaszon. Országos átlagnak (14,77\%) megfelelo a Natura 2000 külonleges madárvédelmi területek aránya

(HUKM10oo2 Kis-Sárrét) (14,53\%), am azt mutatja, hogy a II. mintaterületi belvízvédelmi szakaszon magas ezen európai jelentőségú oltalom aránya. Kiemel szerepét támasztja alá az is, hogy a Kis Sárrét különleges madárvédelmi terület elentőss része a Sebes-Körös menti belvízvédelmi szakaszon húzódik számos ritka ragadózómadár köztük a barma réthéja kék vércse élőhelyéül szolgálva. (httpi)

\section{Védettségek megoszlásának}

elemzése a mintaterïletek belvízjárta részein (táblázat 7-8. oszlopai)

Az I. (Rába menti) mintaterület 35,07\%-a érintett közvetlenül belvízi elöntéssel belvízjárta terület $18,26 \%$-a védett, z egyes védettségek területi arányaio d a

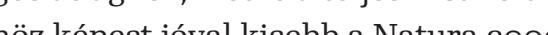

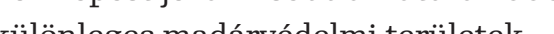
lletve az Orstágo Ölolgai Haloz hetve az Országos Okologiai Hálozat mag- és pufferteruleteinek teruleti aránya. A Natura 2000 kulonleges természetmegorzési teruleteinek aránya az országos átlagtól jelentósen nem tér el, de a kisalfoldihez képest magasabb részarányú. Kiemelkedỏ viszont az ökoló giai folyosok aranya; az I. mintaterüle belvizjarta teruleteinek $17,40 \%$-a tartozik ebbe a kategóriába. (2-3. ábra)

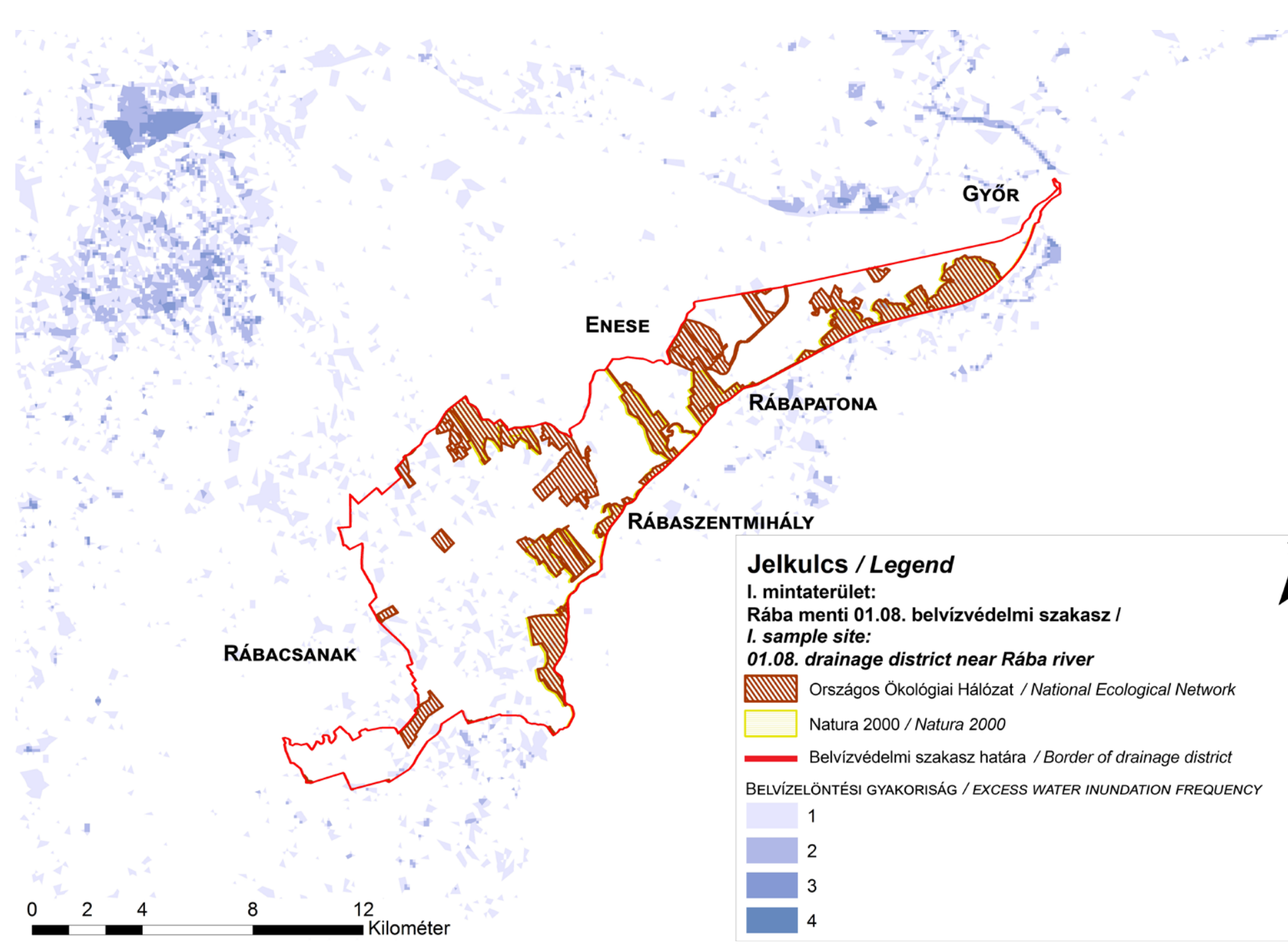

2000 areas and the National Ecological Network (NEN). 10.8\% (that is 1443.92 hectare) of the sample area has been designated as Natura 2000 SAC (ID No. HUFH30oo5 Hanság, HUFH2oo11 Rába); the proportion of the ecological corridor is $43.36 \%$ of the II. sample area $(12.04$ drainage district near Sebes-Körös river is covered by any of the analyzed categories so totally 1560074 hectare is protected. Total distribution of protected areas is very high, $80.45 \%$, which is due to the fact that in many patches more protected areas cover the same part of the sample area. Anong the prort the sample ära. Among the protected a

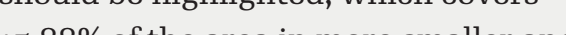
$15.88 \%$ of the area in more smaller and the parea (Picture 1) There is not any protected (P) vanscape areas, hature conser$\checkmark$ ation areas in this drainage district. SPA (ID No. HUKM10ooz Kis-Sárrét)
(14.53\%) corresponds to the national average (14.77\%), which shows that the proportion of this European nature protection category is high in this sample area. Its special role is also confirmed by the fact, that a significant part of Kis-Sárrét Special Protection Area locates in the drainage district near Sebörös river serving as a hitat for many rare raptors, including western marsh harier, redfoted folon. (httpu)

Analysis of distribution of

rotected areas in areas exposed to excess water in sample sites (columns $7-8$ of the table) $35.07 \%$ of the I. sample area is directly exposed to excess water. $18.26 \%$ of thes areas are under protection, the total distribution of protected areas is $38.16 \%$ Compared to the national average and the whole Little Plain, the ratio of Natur of the National Ecological Network is 2000 SAC does not differ significantly 2000 SPA and the core zone, buffer zone 

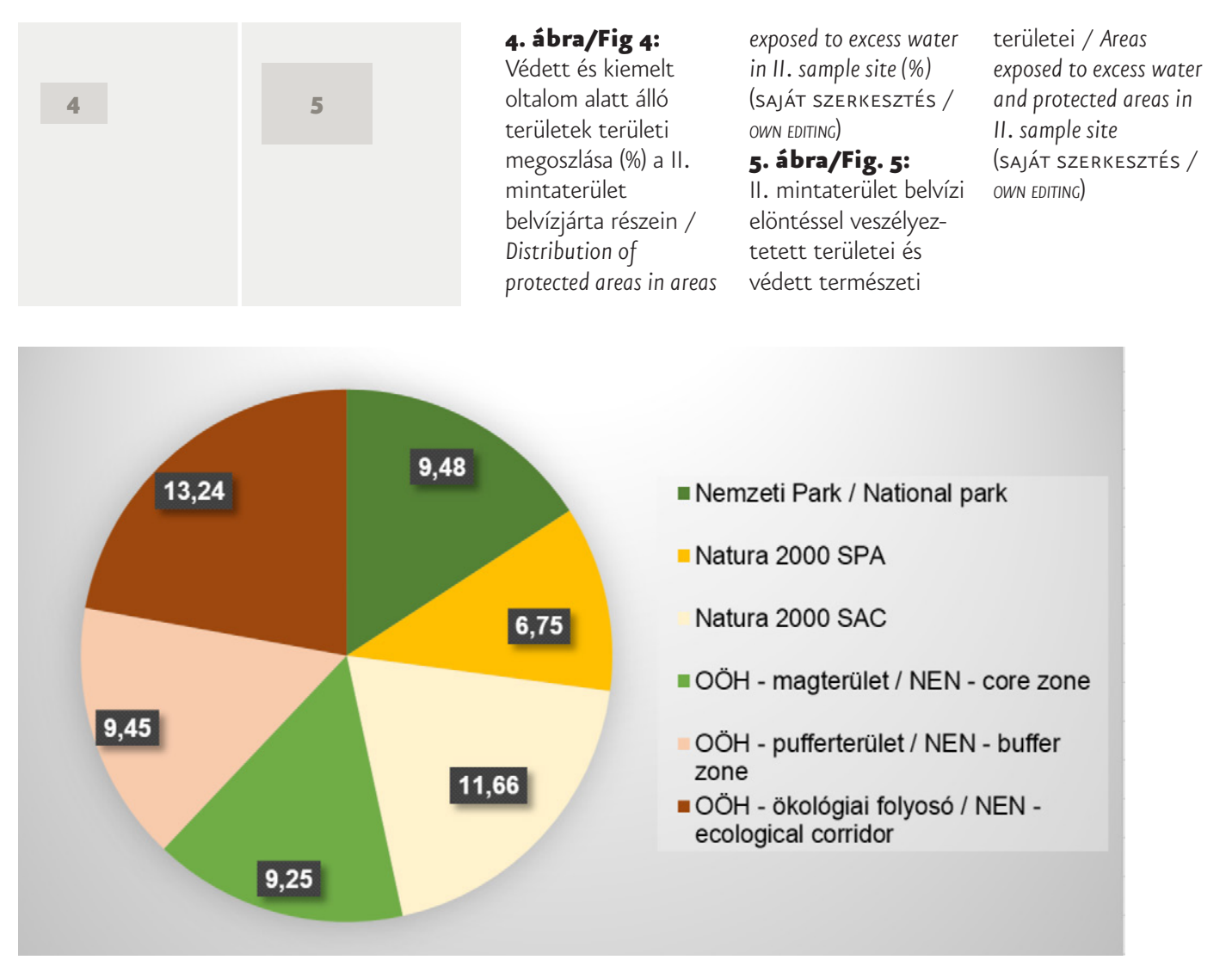

A II. (Sebes-Körös menti) mintaterület esetében 38,85\%-os a belvízi elöntés által veszélyeztetett területek aránya. E belvízjárta területek mintegy $22,31 \%$ védett, a védettségek területi arányavédett, a védettségek teruleti aranyaami annak köszönhető, hogy sok helyen dik. A terület $948 \%$ a a Körös-Mazos Nemzeti Park része A gazdog maros Neńs kö Park náse. A gazdag madávilág kovvetkeztében magas a Natura tek aŕnya, küll̈nore világa kije lo

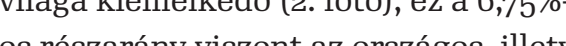
os afföldi enter az arsźgos Ölón mind a ma na par

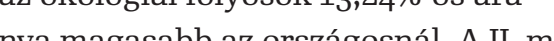
nya magasabb az orszagosnal. All.mintateruloten, a belwzjarta terileteken a védettseg alutt allo ter öro tek oosszesitett aránya és a védett területek osszteruletenek arannya is magakozó adatoknál, ami a Sebes-Körös ment terület ökológiai szempontból értékesebb adottságaira utal (4-5. ábra). A mintaterületek belvízjárta részein kimutatott védettségi arányoknak és az országos védettségi arányoknak (táblázat 2., 5., 7., illetve 2., 6., 8. oszlopa-

nak) az összevetését a 6. és 7. ábrán látható diagramok szemléltetik. Az 1. táblázatban összefoglalt eredmények tehát igazolják, hogy az elemzett két mintaterületen a belvízjárta tájrészletek fontos szerepet töltenek be a védett természeti területek rendszerében (az elemzett kategóriákban), elsősorban a nemzeti parkok Natura különleges természetmegôrzési teriitek, valamint az Országos Ökóngiai Hálózat elemeinek esetében. $A z$ redményeter fetéteresing rint tovább erőśiti majd a bioszfér rezrút kes tava lápón á Remsari területek integrál A vizsgál belvízver Aül azgát bevizved ćss azonbu nem

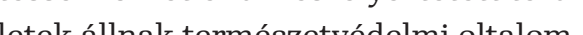
att

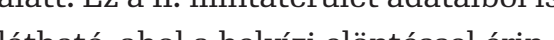
tett to, ahol a belvzi lontesselerintett teruletek $22,31 \%$ a, a teljes mintate rulet 43,36\%-a vedett. Itt a belvizjarta es a belvzzel nen veszelyeztetett terulete közösen alkotnak olyan értékes élőhely együtteseket, amelyeknek köszönhetőe a védettségeik százalékos aránya meghaladja az országos átlagot. Mindez az I. mintaterületrố is elmondható, bár ott a belvízjárta és belvízzel nem veszélyezte-

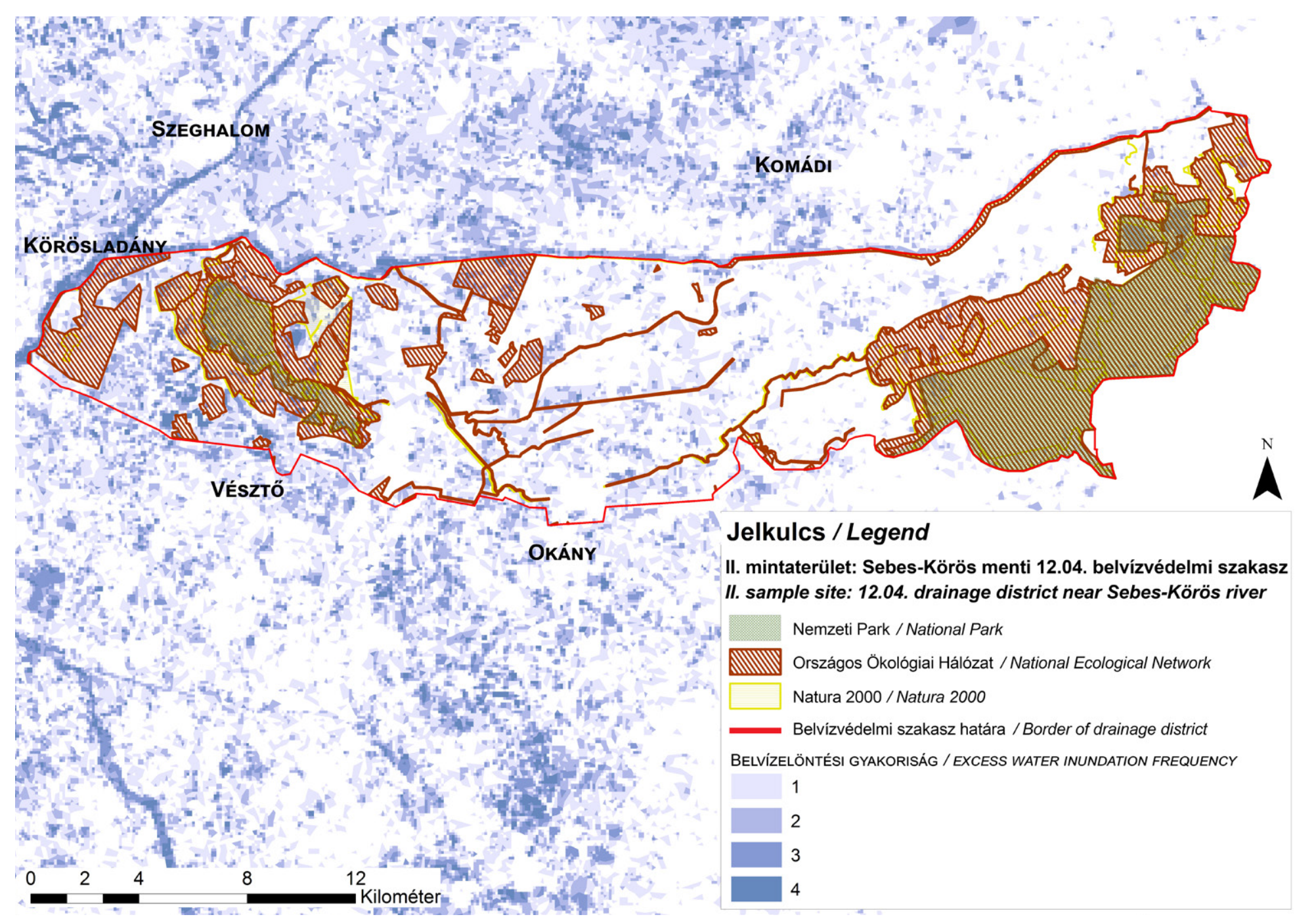

from the national average, but it is higher than in the Little blan. However, the proportion of ecological corridors is prominent: $17.40 \%$ of the areas exposed to excess water in the I. sample site falls under this category. (Figure 2-3.) $38.85 \%$ of the II. sample area is directly exposed to excess water. About $22.31 \%$ for the a distribution of protected areas is $59.83 \%$ which is due to the fact that in many patches more protected areas cover the same part of the sample area. 9.48\% of the area exposed to excess water is part of the Körös-Maros National Park. As a consequence of the rich bird population, the proportion of Natura 2000 SPA is significant (Picture 2.), but this share $(6.75 \%)$ is lower than the national and the Great Plain's values. Among the elements of the National Ecological Network, the proportion of buffer areas (9.45\%) and ecologica of buffer areas (9.45\%) and ecologica corridors $(13.24 \%)$ is higher than the the areas e. total distribution of protected areas and the distribution of protected areas total area is also higher than in the I. sample site, which indicates that the area among Sebes-Körös river is ecologcally more valuable. (Figure 4-5.)

\section{The comparison of the proportions} of protection in sample sites' areas exposed to excess water and in national scale (columis 5,7 and $2,6,8$ of the Figur 6 ond 7 The summarized results in Table 1 . The sur relatively often to excess water in the two sample sites, play an inpotant in the system of protected ares (in the analyzed categores), mainly is (he case of nation the elent Network. Accoling to the results will be tour assumpto tege lege protected bogs, set-merves, ex Ramser

As the resits shew withses. analyzed drainage districts not only 


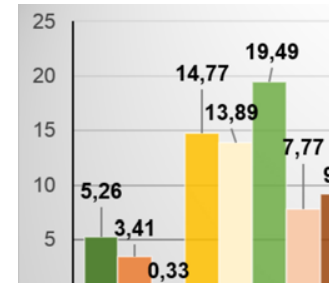
\begin{tabular}{lll}
$1,64 \quad 2,56$ \\
1 & 1 \\
\hline
\end{tabular}

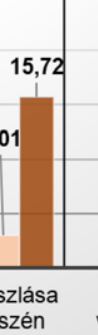

11

$2,51,4,08$

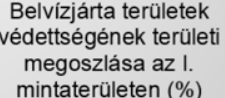

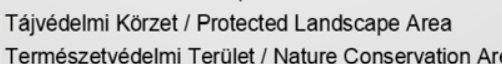
- Natura 2000 SPA OOH-magterilut/ $/ \mathrm{NEN}$ - core zone OÖH- Obologgiai folyoso / NEN - ecological corrid

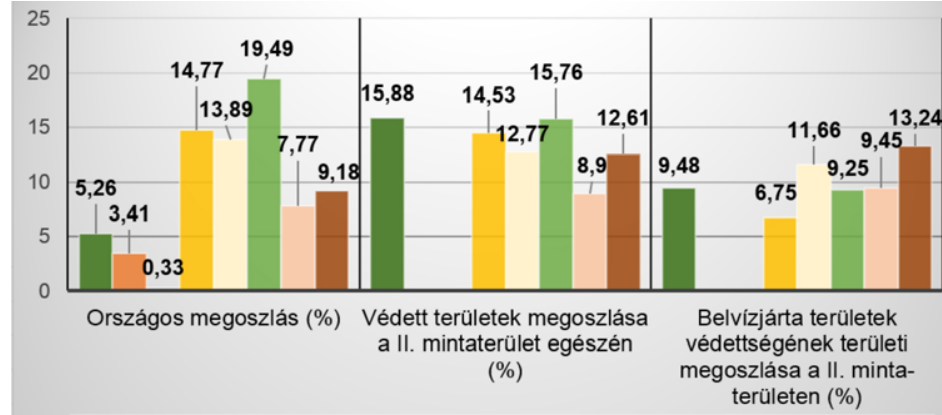

Nemzeti Park / National park

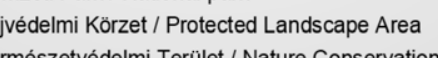

Natura 2000 SPA

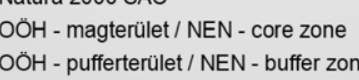

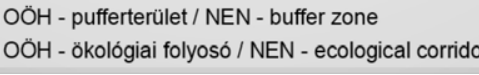

tett területek védettségének százalékos megoszlása között nem jelenik meg a II. mintaterülethez hasonló szignifikán különbség. Míg a belvízjárta területek 18,26\%-a, a teljes mintaterület 22,73\%-a védett. A vizsgált belvízvédelmi szakaszok között - természetvédelmi szempontból - megfigyelhető különbségek is alátámasztiák az országos szintủ elemzés létjogosultságát és szükségessés t.

\section{ÖSSZEGZÉS}

A természetvédelmi szempontbó

kiemelt területek és a belvízjárta területek összefüggéseinek feltárása rámutatott, hogy a vízjarta, iloszakos vizbor-

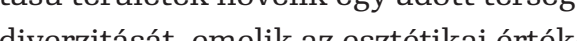
diverzitasat, emolik az esztetikai erteke

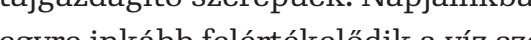

egyre inkább felértékelodik a viz szerepe a tájban a klimaváltozás es más globâlis változások miatt. A tobbnyire nagy csapadékmennyiséggel járó, heves esozések utann kialakulo belvizek időszakosan jelentkezo viztobbblete és vízfelülete sajátos élőhelyeket biztosít, amelyek sok esetben igazi ritkaságokat is magukban
rejtenek. A jelenlegi belvízjárta területek legnagyobb része az egykori - folyószabályozások előtti - vizenyős, mocsaras
6. ábra/Fig. 6:

6. abra/Fig. 6:
Védett és kiemelt
oltalom alatt álló

the areas exposed to
excess water in I.

excess watare in I.
sample site $(\%)(3$.

(SAAT́T SZERRESZTÉs

Own Ebrinc)

Védett és kiemelt
oltalom alatt álló

oltalom alatt álló́
terüuletek megoszlasa

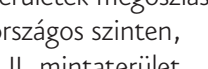

agézzén, illetve a ll. elviziártat területein
(b) / Distribution of protected areas in

group), in the ll. sample

site 2 . groupl) and in
the areas exposed to

excess water in 11.
sample site $\%)(3$.

group)
(SAAÁT SZERKESZTÉS

own Errinc) those areas that are exposed to excess water are under protection. This can be seen from the data of the II. sample site, where $22.31 \%$ of the areas exposed to excess water is under protection, but at the same time $43.36 \%$ of the total sample area is protected. Here areas exposed to excess water and areas not endangered by excess water form together valuable habitats; as a result of this, the percentage of thei protected areas exceeds the of the average. All this can be the nationa the I. sample site, although there's not so significant difference not so signifcant diference betwe the percental proportion of areas not exposed to excess water. In sample site the distribution is the and $22.73 \%$ in favor of areas not expose to 2 a to $x$ - for The - beswenthe andyzedsaplest - between the a of the analysis at national level.

CONCLUSION

The analysis of correlation of protected areas and areas exposed to excess wate has confirmed that periodically watercovered areas exposed to excess wate increase the diversity of a given are increase its aesthetic value and play role in enriching the landscape. Nowadays, the role of water in the landscap is increasing due to climate change and other global changes. The periodically appearing excess waters that ar created mostly after heavy rainfalls, provide specific habitats, which in many cases also contain real singularities. excess water have developed on form wetlands, which could be found before river regulations. In Hungary, in many smaller or larger patches, such as in the Hortobágy National Park or along the Ürös river, which has been ang thed in this study there are also ancient rasslands and other areas exposed to excess water, that have a special flora and fauna; therefore they are worthy for protection Drainage canals should lso be mentioned, which can be avaluable habitat, thus play a diverse role analyzed sample areas, that a significan proportion of areas exposed to excess ater have a high ecological value and a result of this, they are under protecton. On behalf of proving the ecological sificance of these areas, a nationwide to andysis, used in this study, is needed to reveal the correlations between areas exposed to excess water and protected areas. This process will be carried out in the next phase of the research.

Research work was supported by Blue Planet Climate Protection Foundation. MOLNARV. ATTLA, LUKACS BALAZS ANDRAS (2014): Belvizes Élet és Tudomány 2014 (15). pp. PALLAA IMRE (2004): Belvizek és aszályok Magyararorzzágon. Hidrológiait tanulmanyyok. Közlekedés D Dokumentácicios Kft., Budapest. ISBN 96355523823 PP. $17-35$.

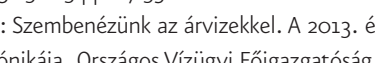
Budapest. pp. 23-28.

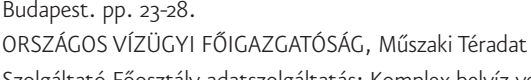

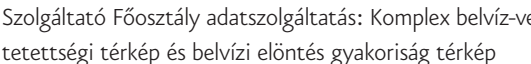
térinformatikai dadatázisa. Atadáas dácuma: 2020.11.1.

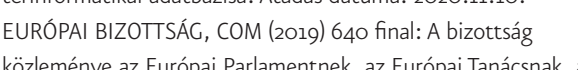

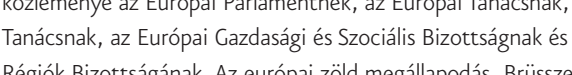
Régiók Bizottságának. Az európai zöld megállapodás. Brüsszel.

2019.12.1.1.

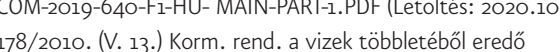

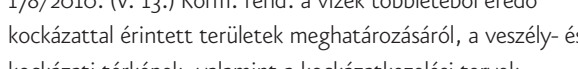

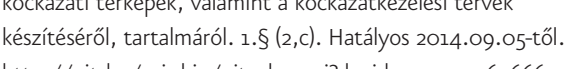

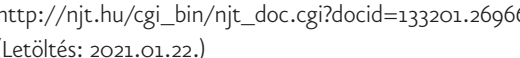

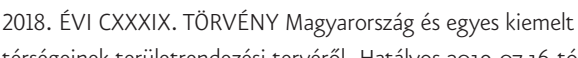

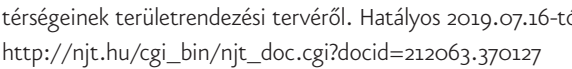
(Letöltés: 2021.01.20.

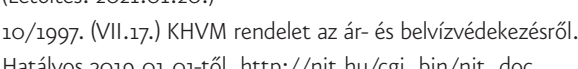

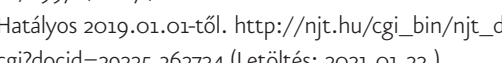

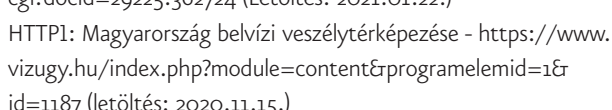
id=1187 (letötés: 2020.11.1.5

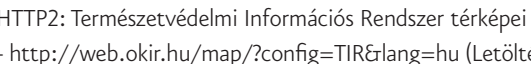
2020.10.29.

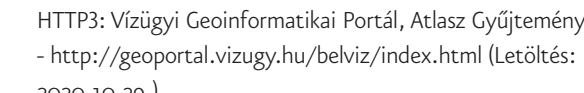
HTTP4: Natura 2000 területek- https://natura.2000. hu/hu/

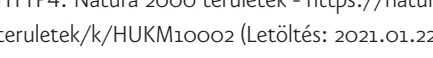

